\title{
MANAGERIAL ACCOUNTING AS AN ELEMENT OF INFORMATION RESOURCES MANAGEMENT OF AN ENTERPRISE
}

\author{
Mykola Matiukha \\ Alexander Rovnyagin ${ }^{1}$ \\ ${ }^{1}$ Department of Accounting and Audit \\ Kyiv National University of Technologies and Design \\ 2 Nemyrovych-Danchenko str., Kyiv, Ukraine, 01011
}

\begin{abstract}
The questions of the information resources organization and formation mechanism of an enterprise through financial and managerial reporting data and accounting data prism are highlighted. The sequence formation elements and enterprise information resources use are considered. The formation of the enterprises information resource, based on managerial accounting, is studied, which is a priority aspect of modern decision-making support, as well as other components of business tools - financial management and audit.

Information resource management has certain functions that are general and inherent in all business systems. The nature of the prepared reports and information filling of the financial statements are subordinated to general objectives. That is, it contains a range of financial information that should be publicly available and useful to a wide range of users and decision-making, and not specifically devised to the needs of a particular group or set of decision-making. Managerial reports are specialized reports that are designed either for a solution of a specific decision or for a specific manager.

The directions of the information resource management development on the basis of information technology use and information technology impact on the accounting development are disclosed.

Keywords: managerial accounting, managerial reporting, information systems, information technologies, information resource.
\end{abstract}

DOI: $10.21303 / 2504-5571.2020 .001045$

\section{Introduction}

An information resource of an enterprise is an accounting-based system that is implemented and provides managerial decision-making functions. Information resource elements are based on the modern division of accounting into financial and managerial, due to modern formation processes and information presentation for the enterprise management needs. In the system of internal management there is always the possibility of deepening analytical work through the use of managerial accounting data and reporting, that is, the possibility of conducting a comprehensive economic analysis and evaluation of the effectiveness of economic activity. This opportunity appears through the development of data processing technologies, the emergence of new organizational and methodological approaches towards the use of the enterprise information resource. In this connection, relevant issues of managerial accounting are: results orientation of information provision to the goals and interests of the enterprise management, use of all sources of information for decision-making, lack of regulation by government structures, information complexity, study of all enterprise aspects, accounting integration, analysis, planning and decision making; maximum confidentiality of information results in order to secure trade secrets.

Users require a separate selective information, which should have certain distinctive parameters, inherent in different analytical processing methods, to be optimized according to the criteria of information interests. Thus, the owners analyze the information to increase the return on equity, to ensure the stability of the company. Lenders and investors analyze the information to minimize their risks on loans and deposits. Accordingly, the study of the formation of the enterprises information resource, based on managerial accounting, is a priority element of modern decision-making support, as well as other components of business tools - financial management, audit. 
As noted by Belukha M.T. and Holov S.F. information resources are identical to resources such as labor, material, energy and other resources. So, in the economic field, we can talk about information-based economy and information sphere - leaders of different levels, scientists, specialists and employees $[1,2]$. In this instance, the problem of obtaining information resources and their application in the managers' work is actualized, which gives a significant economic impact without additional capital raising $[3$, p. 21$]$.

In addition, an element of the information systems development is the cybernetic approach. According to which the management system is characterized by the presence of two interconnected components:

- management subject - the managerial apparatus of an enterprise that carries out the formation of goals and decision-making (which are then formalized in the form of plans), and provides control over their implementation;

- management object - an enterprise, that executes the tasks [4].

Despite the different understandings of the correlation between managerial accounting and information systems, information resources are information capital [5, p. 83] that can be evaluated by a set of information assets and intellectual capital that can generate revenue for an enterprise.

Regardless of different types of information, differences in interpretation of its essence, quantitative and qualitative characteristics, methods of information resources manipulation, information is one of the defining elements of an innovative management technology in terms of information society [6].

As noted in M. I. Skrypnyk's research, the consideration of the information support system of decisions should be based on scientific fundamental research and development. The gap between the practical and theoretical foundations of the managerial accounting information system now requires new research and the conceptual provisions development in the field of processing and presentation of data that are grouped on an itological basis [7].

A classic example of managerial accounting elements consideration is the research, conducted on a complex approach to accounting automation, which should be implemented in solving such tasks [7, p. 16]:

- defining the role and place of accounting in the enterprise management system;

- classifying task complexes types, as well as tasks of information system of accounting, control and analysis;

- identifying hierarchical levels that are solved in the accounting information system, as well as clarifying the nature of system-forming relations between them, elements, complexes of tasks and objectives;

- establishing conditions and limits of the accounting information system validity;

- control and analysis;

- building a conceptual model of automated processing of accounting information;

- creating an accountant's information language that will allow a user to work in a dialog mode;

- comprehensive consideration of theoretical and methodological bases of accounting;

- systematic solution of accounting, control and analysis problems;

- the use of tools for accounting, control and analytical processes modelling;

- organizing an automated research system; forecasting of economic and financial activity of an enterprise;

- development of modern ways of communication in a dialog mode with the information system of accounting, control and analysis;

- creating automated decision-making system on the basis of integrated approach.

Methodologically, the systematic approach is based on the ideas of integrity, purposefulness and the organization of management objects, their internal activity and dynamism.

The research on the subject of formation, use and development of modern accounting information technologies have been accentuated in the works of such scientists as M. M. Benka [8], S. V. Ivakhnenkov [9] and others. The scientific literature discloses problems of managerial accounting formation and development as an effective system of information provision for deci- 
sion-making, but under the current managerial accounting, adaptation conditions to national rules and approaches, together with the world economic achievements, require the improvement of the theory, methodology and practice of information provision enterprises.

The research analysis allows to confirm that the majority of authors, when disclosing the essence of the category of managerial accounting, focus on such key criteria as: filling; purpose and application.

The obtained theoretical and practical developments in managerial accounting and reporting as the basis of enterprises information resource formation are of great importance for the accounting theory development and the implementation of its provisions in the practical activity of economic entities.

However, while not detracting to existing accounting and reporting contributions, information resource management remain unresolved and requires further study, the problem of minimizing and optimizing expenses in generating and presenting the information to users.

Aim of the research is to determine managerial accounting as an element of information resources management of the enterprise, to compare the criteria of information content of the regulated (financial) and management reporting for the formation of the information resource of an enterprise.

\section{Materials and Methods}

The research used scientific methods, based on the dialectical method of cognition and the objective laws of economics. Theoretical aspects of information systems were investigated on the general trends of the accounting development, the method of generalization was used to formulate the conclusions of the study.

\section{Research and results}

In the context of an enterprise management system, managerial accounting and reporting is part of a general business information system in which managers have to make decisions about allocating scarce economic resources. The main way to solve this problem is to create and manage an information base for decision making, which ensures efficient resources allocation of an enterprise and, in turn, information resources as well.

Information resource management has certain functions that are general and inherent in all business systems:

- identifying and presenting corresponding information;

- information accumulation and systematization;

- analyzing and interpreting the collected information;

- presenting information in accordance with the needs of individual managers.

The sequence of enterprises information resources formation and use can be divied into two stages (Fig. 1).

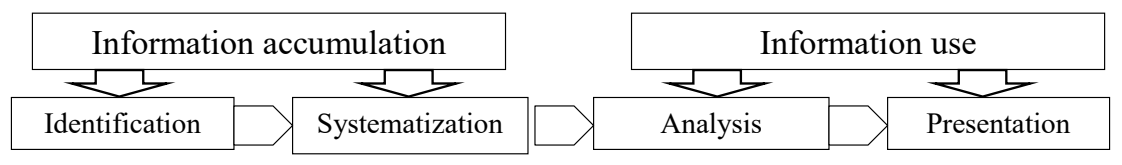

Fig. 1. The formation sequence and use of information resources of an enterprise

The consecutive steps of managing the information system of an accounting resource can be divided into two phases. The first two phases are about preparation, while the last two elements are linked to the use of collected and systematized information. Accordingly, managerial accounting as an element of the information resource can be examined as a form of information service, clients of which are managers [10]. Thereby, this poses the question of what information is needed for specific clients in a time interval and information scale. There are four broad areas of decision-making that define the necessary information base for managerial accounting: 
1. Targets and plans development. Managers are responsible for setting the mission and goals of the business, strategies and plans development in order to achieve those goals. Effective management should ensure that the information collected will be needed to develop corresponding goals and strategies. Information support should ensure the generation of financial plans that determine the potential outcomes specific strategies adoption. Managers can use financial plans to evaluate each individual strategy and use it as a basis for adopting a specific development strategy;

2. Performance and control evaluation. Information stream management should forsee an overview of the enterprises business activity by agreed criteria. The current question is the use of non-financial indicators, which are increasingly being used to evaluate performance alongside financial indicators. Information resources management should be carried out in accordance with the managerial structure of enterprise management. Information resource management should be broken down by organizational units to ensure real productivity according to the planned task. Therefore, the actual results will be compared to the plans to see whether the performance is better or worse than expected. If there is a significant difference, investigation and corrective action should be applied if necessary.

3. Resource Allocation. Resources, available to businesses, are limited and it is the managers responsibility to ensure their effective use. Decisions on issues such as the optimal level of production, the optimal combination of production commodities and the appropriate type of investment in new equipment require additional managerial information.

4. Expenses and revenues determination. Managerial decisions require the identification and estimation of costs and revenues from the implementation of a particular course of action, for instance providing services, creating a new product or closing a unit. The solution will be to determine the cost over benefits. The accountant should provide managerial decision-making information, providing information on specific costs and benefits. In some cases, determining, estimating costs and benefits can be extremely complicated to quantitatively evaluate; however, in some cases approximate data representation is sufficient.

An enterprise information resource can be used by managers to make decisions for the following areas: long-term plans and strategies development, performance and management evaluation, resources allocation, and costs and benefits determination. Therefore, information resources are separate documents and document arrays, in information systems. Users of information resources are entities that use the information system to obtain the necessary information [11].

Another direction of the information resources development management is based on the use of information technologies. The impact of an information technology (IT) on the accounting development can hardly be overestimated. The ability to use IT enables to process large volumes of information, which means reports can be generated quickly and accurately. Certain reports can be generated daily or even in real time. This approach is vital for companies, operating in a highly competitive environment, having a risk of losing competitive decision-making, based on inaccurate or old data. IT also made it possible to disseminate business information more broadly worldwide. With the development of IT implementation, more and more employees of all levels are able to access appropriate information and reports to make decisions and take corresponding action. IT has made it possible to present management reports more precise and in greater detail and variety than could be expected with the use of a manual system. Furthermore, it has made sophisticated measurement systems that provide information needs at relatively low cost, possible to use. Managers can use IT to evaluate proposals, using variable factors (such as product price, expenses, product value, etc.), to increase or decrease the size of key factors to create a range of possible decision-making scenarios. The information revolution is gaining momentum, and most likely, IT will influence the methodological basis of enterprises information resource management. Particularly important in this direction is the ability to evaluate information, expanding the scale of the ability to make data judgments in a short amount of time. Increasingly, in managerial accounting, IT is being considered not only as a way of improving the timeliness and accuracy of management, but also an important source of competitive business advantage [12, 13].

Accordingly, as the traditional role of information resources in doing business is changing, the accountant plays the role of manager. IT have enabled the accountant to remove a vast amount 
of the routine work, involved in preparing managerial reports, and have provided an opportunity to take a more active position to the business management. This results in the accountant's becoming a more significant member of the management team as well as directly involved in planning and decision making. At the same time, measuring the role of an accountant in the information resources management area should have priority advantages in the managerial accounting development as a significant component of the enterprises information resource. The accountant, as part of a multifunctional management team, should have a greater awareness of strategic and operational issues, a deeper understanding of the manager information needs, and a profound understanding of business profitability value (product value). This approach will have a positive influence on the development and information resource management progress, considering the specific structure and business processes [14]. Subsequently, an enterprise is creating an information resource system, which is an organizationally ordered set of documents, information technologies, including the use of calculus and communication machinery that implement information processes.

Taking IT elements in planning into account, decision-making and business control, as well as providing management accounting information for these purposes, managerial reporting should provide the basis of the information resource in achieving set goals. This role should add value to the business and improve its competitive position. Accounting through the prism of financial and managerial accounting should provide an information resource to meet different information needs, complementing each other. In this context, it is necessary to highlight the legitimate information content qualities of the entreprise information resource (Table 1).

\section{Table 1}

Comparison of regulated (financial) and management reporting information content criteria for formation of the information resource of the enterprise formation

\begin{tabular}{|c|c|c|}
\hline Criteria of information content & Financial reporting & Managerial reporting \\
\hline Type & $\begin{array}{l}\text { Generally accessible, useful for a wide } \\
\text { range of users, intended for decision } \\
\text { making }\end{array}$ & $\begin{array}{c}\text { Custom designed to solve a specific task, } \\
\text { usually for a specific user. }\end{array}$ \\
\hline The level of detail & $\begin{array}{c}\text { Aggregated information over a period of } \\
\text { time }\end{array}$ & Detailed \\
\hline Regulation & External & Internal \\
\hline Periodization & Regulated (annual, quarterly) & Per request, if necessary \\
\hline Timeliness (Time factor) & Past events display & Display both past and prognosed data \\
\hline Range and quality of information & Exact data expressed in monetary terms & $\begin{array}{c}\text { Approximate, expressed as a monetary } \\
\text { meter and in natural }\end{array}$ \\
\hline
\end{tabular}

Types of reports. The financial statements content is subordinated to the general objectives. That is, it contains a range of financial information that should be publicly available and useful to a wide range of users and decision-making, and not be specifically tailored to the needs of a particular group or set of decision-making. Managerial reports are special reports that are designed either for a specific decision or for a specific manager.

The level of detail. Managerial reports provide users with a wide range of performance and business positions indicators over a certain time period. As a result of manipulation, the information becomes quite aggregated, and the details are often lost. Managerial reports should provide significant detail to help users make an informed decision by a certain factor.

Regulation. Accounting statement is standardized and compiled in accordance with accounting rules that comply with the standard content and format. Legislation and accounting rules establish these rules. Because managerial accounting reports are for internal use only, there are no external source rules for the form and content of the reports. They can be designed to meet the needs of specific managers. 
Periodization (certain time period (interval). The standard reporting term for enterprises is the annual (quarterly) basis. Managerial reports can be prepared for management information needs. For many enterprises, reporting is required on a daily, weekly or monthly basis to track the tendencies. And in this category of meeting information needs are only managerial reports. In addition, special reports may be used when necessary, for example, to evaluate the proposal to purchase equipment for a separate production process performance.

Timeliness (time horizon). Financial statements reflect the performance and position of an enterprise in the previous period - in fact, they are reversed. Management requires forecast information (the amount of possible contractual receipts, or the amount of payments to creditors in the future). Sometimes enterprises provide prognosed information to other users in an effort to raise capital or contend unwanted takeover rates.

Range and quality of information. A financial statement focuses on information that can determine the monetary expression of an entity. Managerial reports may contain information of any content, characterizing both the material medium and the non-financial information. The place of financial accounting is more accentuated on the use of objective, verified evidence in preparation of reports. Managerial reports can use less objective and even more approximate information, necessary for managers.

Respectively, the information resources of an enterprise should be determined, based on the parameters of formation and financial and management reports presentation. Managerial reports are less restricted than financial statements, they may be based on different sources and use different degrees of reliability [15-17]. The only real approach that should be used when evaluating the significance of information for executives is how to improve the quality of decision making. The difference between managerial and financial statements indicates that there are differences between the information needs of managers and other users. While there are undoubted differences, many coincidences of these needs also exist. For instance, managers will sometimes be interested in getting historical information - an overview of the executed transactions that are made available to other users. Similarly, other users will be interested in receiving prognosed information, such as financial - planned profit margins and non-financial - the status of an order for new product sale. The differences between these two information areas reflect to some extent the differences in access to financial information. Managers have a much greater need to control the form and content of information, which they receive. Other users should rely on what managers are prepared to provide, or what financial reporting stipulations they require.

The amount of financial statements changes over time, and the tendency of information support to prevent a loss of competitive advantage and uncertainty of users about the forecast data reliability leads to an increase in alternative sources of information role such as managerial reporting - detailed and scaled, accessible for managers.

Further, there is a preconceived attitude towards the enterprises information resource system, which prioritises the benefit of providing information to external users, which is typical of the domestic accounting development. However, there is a need for a clear and unbiased attitude towards the requirements of external and internal users. Today, the management of accounting systems is focused on the current needs of international financial reporting standards, which are different from the requirements of internal reporting [18]. External information security requirements remain to have a significant impact on management reporting, therefore managers need to be aware of the external users' information expectations.

The information resource development not only for private sector enterprises, but also for institutions, activities of which are not related to profit making, rather to achieving a social impact (charitable foundations, associations, universities, national and local authorities and trade unions) is quite relevant. Such institutions have specific information needs, depending on their type of activity. In particular, by achieving the target of their objective in the most efficient way.

\section{Conclusions}

The modern basis for the formation of the enterprises information resource is data that is combined and formed by traditional accounting. In view of the stated, the management of infor- 
mation resources should be formed, based on the principles of relevance, reliability, periodicity, comparability that are typical for modern accounting. The basis of the enterprises information resource should be managerial accounting and managerial reporting, formed, based on the latter. At the same time, the principle of supplementing the financial reporting indicators with the indicators of managerial reporting for the complete and non-costly formation of the enterprises information resource in accordance with the nature of the content, level of detail, scale, periodization, regulation, and evaluation and quality of information should be adhered to.

\section{References}

[1] Belukha, M. T. (2004). Forensic accounting. Kyiv: Volia Publishing Company, 656.

[2] Holov, S. F. (2014). Futurology of accounting. Bulletin of the National university «Lviv Polytechnic». Management and entrepreneurship in Ukraine: stages of formation and development problems, 794, 153-157.

[3] Sopko, V. V. (2006). Accounting in enterprise management. Kyiv: KNEU, 526.

[4] Osmyatchenko, V. O., Oliynyk, V. S. (2017). Modeling the formation of reporting performance indicators for employees. Economic Bulletin. Series: Finance, Accounting, Taxation, 1, 160-166.

[5] Pushkar, M. S. (2017). Creation of scientific theories of accounting and control. Accounting, Taxation and Control: Theory and Methodology. Ternopil, 50-54

[6] Radionova, N. Y. (2016). Methods of forming a balanced indicator system as a tool of strategic managerial accounting. Strategic vectors of socio-economic development at the micro and macro levels. Poltava, 175-178.

[7] Skrypnyk, M. I. (2011). Organization of expenses accounting by expenses centers and responsibility centers. Accounting and Finance APK, 1, 46-49. Available at: http://magazine.faaf.org.ua/organizaciya-obliku-vitrat-u-rozrizi-centriv-vitrat-ta-centriv-vidpovidalnosti.html

[8] Benko, M. M.; Antoshkina, L. I. (Ed.) (2016). The current state and prospects of accounting development and economic analysis of enterprises in Ukraine. Berdyansk: Publisher Tkachuk O. V., 240.

[9] Ivakhnenkov, S., Heorhiadi, A. (2013). Ukrainian businesses' characteristics and the use of information technology: introduction to exploratory studies. Naukovi zapysky NaUKMA. Ekonomichni nauky, 146, 39-45.

[10] Skrypnyk, M., Radionova, N., Vlasiuk, T., Bondarenko, S., Grygorevska, O. (2019). Accounting and Verification of Sustainable Enterprise Development Reporting. IBIMA Business Review, 1-10. doi: http://doi.org/10.5171/2019.873407

[11] Skrypnyk, M. I., Matiukha, M. M. (2015). The itological concept of management accounting and reporting. Current Issues in Economics, 4, 230-238.

[12] Napadovskaya, L. V. (2000). Domestic Control in a Market Economy. Dnepropetrovsk: Science and Education, 224.

[13] Needles, B., Anderson, H., Caldwell, D. (1994). Accounting Principles. Moscow: Finance and statistics, 495.

[14] Hermanson, R. H., Edwards, J. D. (1995). Financial accounting: a business perspective. Richard D. Irwin, Inc., 670.

[15] A «Small Business Act» for Europe (2008). Commission of the European Communities, 21.

[16] Taxation of SMEs: Key Issues and Policy Considerations (2009). OECD Tax Policy Studies, 18, 166. doi: http://doi. org/10.1787/9789264024748-en

[17] Taxation trends in the European Union (2012). Eurostat Statistical Books, 34.

[18] Simplified Tax Compliance Procedures for SMEs (2007). Final Report of the Expert Group (European Comission), 89. 